\title{
PENGARUH MODEL PEMBELAJARAN KOOPERATIF TIPE TPS (THINK PAIR SHARE) TERHADAP PEMAHAMAN SISWA PADA MATA PELAJARAN FIQIH KELAS VII MTS AL-IRSYADIYAH DERMOLEMAHBANG SARIREJO LAMONGAN
}

\author{
Siti Mukhoyyaroh \& Syaiful Jazil \\ (Alumni IAIN Sunan Ampel Jurusan PAI \& Dosen IAIN Sunan \\ Ampel)
}

\begin{abstract}
Abstrak
Masalah yang diteliti dalam tulisan ini adalah: 1) Bagaimanakah penerapan model pembelajaran kooperatif tipe TPS (Think Pair Share) pada mata pelajaran Fiqih kelas VII MTs Al-Irsyadiyah Dermolemahbang Sarirejo Lamongan; 2) Bagaimanakah pemahaman siswa pada mata pelajaran Fiqih kelas VII MTs AlIrsyadiyah Dermolemahbang Sarirejo Lamongan; 3) Bagaimanakah pengaruh model pembelajaran kooperatif tipe TPS (Think Pair Share) terhadap pemahaman siswa pada mata pelajaran Fiqih kelas VII MTs Al-Irsyadiyah Dermolemahbang Sarirejo Lamongan.

Teknik pengumpulan data yang digunakan dalam penelitian ini meliputi: 1) Observasi untuk memperoleh data tentang penerapan model pembelajaran kooperatif tipe TPS (Think Pair Share); 2) Angket untuk memperoleh data tentang penerapan model pembelajaran kooperatif tipe TPS (Think Pair Share) dan pemahaman siswa terhadap mata pelajaran Fiqih; 3) Interview dan dokumentasi digunakan untuk memperoleh data gambaran umum objek penelitian. Analisis yang digunakan adalah: 1) prosentase dan 2) product moment.

Hasil penelitian menunjukkan bahwa: 1) Penerapan model pembelajaran kooperatif tipe TPS (Think Pair Share) adalah baik, hal ini dibuktikan dengan hasil angket yang menunjukkan nilai sebesar $80,2 \%$; 2) Pemahaman siswa terhadap mata pelajaran Fiqih tergolong baik. Hal ini dibuktikan dengan hasil angket yang menunjukkan nilai sebesar 69,9\%; 3) Pengaruh model pembelajaran kooperatif tipe TPS (Think Pair Share) terhadap pemahaman siswa pada mata pelajaran Fiqih kelas VII MTs Al-Irsyadiyah Dermolemahbang Sarirejo Lamongan, berdasarkan hasil analisis diperoleh $r_{x y}=0,208$ dengan jumlah responden 41 sedangkan $r_{\text {tabel }}$ pada taraf signifikansi $5 \%$ adalah 0,316 dan taraf signifikansi $1 \%$ adalah 0,408 . Jadi $r_{x y}$ lebih
\end{abstract}


kecil daripada $r_{\text {tabel }}$ yang berarti hipotesa alternatif (Ha) ditolak dan hipotesis nol (Ho) diterima atau disetujui. Sedangkan jika dikonsultasikan dengan tabel interpretasi nilai " $r$ " dimana nilai $r_{x y}$ berada diantara $0,20-0,40$ yang berarti korelasinya rendah.

Kata Kunci: Think Pair Share, Pemahaman Siswa dan Pelajaran Fiqih.

\section{A. Pendahuluan}

Realita pendidikan menyatakan bahwa pendidikan di Indonesia masih banyak kekurangan dan keterbelakangan. Dikarenakan oleh beberapa faktor, dan salah satu faktor penyebabnya adalah kurang kreatifnya guru dalam menyampaikan pelajaran. Contohnya pada pelajaran Fiqih di MTs A1Irsyadiyah. Disini banyak para siswa yang belum paham benar apa yang telah mereka pelajari dan masih belum dapat menjelaskan apa yang telah diperoleh dari pelajaran tersebut, hal ini disebabkan karena para guru terlalu monoton dalam menyampaikan pelajaran, yaitu hanya memakai metode ceramah saja sehingga para siswa tidak bisa ikut membangun pemahaman mereka sendiri.

Kondisi seperti ini sangat membutuhkan strategi pembelajaran yang dapat melibatkan semua peserta didik sehingga dapat saling membelajarkan melalui tukar pikiran, pengalaman maupun gagasan-gagasan. Salah satu alternatif yang bisa dipilih dalam rangka mengghasilkan pembelajaran yang berkualitas yaitu pembelajaran kooperatif.

Pada model pembelajaran ini siswa diberi kesempatan untuk berkomunikasi dan berinteraksi sosial dengan temannya untuk mencapai tujuan pembelajaran, sementara guru bertindak sebagai motivator dan fasilitator aktivitas siswa. Artinya dalam pembelajaran ini kegiatan aktif dengan pengetahuan dibangun sendiri oleh siswa dan mereka bertanggung jawab atas hasil pembelajarannya.

Tujuan utama dalam penerapan model pembelajaran kooperatif adalah agar peserta didik dapat belajar secara berkelompok bersama temantemannya dengan cara saling menghargai pendapat dan memberikan kesempatan kepada orang lain untuk menggemukakan gagasannya dengan menyampaikan pendapat mereka secara berkelompok. 
Beberapa ahli menyatakan bahwa model ini tidak hanya unggul dalam membantu siswa memahami konsep yang sulit, tetapi juga sangat berguna untuk menumbuhkan kemampuan berpikir kritis, bekerja sama, dan membantu teman. Dalam pembelajaran kooperatif, siswa terlibat aktif pada proses pembelajaran sehingga memberikan dampak positif terhadap kualitas interaksi dan komunikasi yang berkualitas, dapat memotivasi siswa untuk meningkatkan prestasi belajarnya.

Unsur-unsur dasar dalam pembelajaran kooperatif menurut Lungdren (1994) sebagai berikut: 1. Para siswa harus memiliki persepsi bahwa mereka "tenggelam atau berenang bersama". 2. Para siswa harus memiliki tanggung jawab terhadap siswa atau peserta didik lain dalam kelompoknya, selain tanggung jawab terhadap diri sendiri dalam mempelajari materi yang dihadapi. 3. Para siswa harus berpandangan bahwa mereka semua memiliki tujuan yang sama. 4. Para siswa membagi tugas dan berbagi tanggung jawab di antara para anggota kelompok. 5. Para siswa diberikan satu evaluasi atau penghargaan yang akan ikut berpengaruh terhadap evaluasi kelompok. 6. Para siswa berbagi kepemimpinan sementara mereka memperoleh keterampilan bekerja sama selama belajar. 7. Setiap siswa akan diminta mempertanggung jawabkan secara individual materi yang ditangani dalam kelompok kooperatif. ${ }^{1}$

Pemahaman anak didik terhadap suatu pelajaran bukanlah sekedar tahu, akan tetapi juga menghendaki agar siswa mampu memanfaatkan bahan-bahan yang telah dipelajari dan dipahami. Kecenderungan yang hanya sekedar mengetahui tetapi tidak mengerti dan memahami secara mendalam materi yang disampaikan akan mudah hilang dan tidak membekas serta tahan lama dalam otak. Akan tetapi apabila materi pelajaran itu benar-benar dimengerti dan dipahami secara mendalam oleh siswa maka mereka akan siap memberi jawaban-jawaban yang pasti atas pertanyaan-pertanyaan atau berbagai masalah yang berkaitan dengan itu.

Dalam model pembelajaran kooperatif terdapat banyak tipe, salah satunya adalah tipe TPS (Think Pair Share), Ciri utama pada model pembelajaran kooperatif tipe TPS (Think Pair Share) adalah tiga langkah utamanya yang dilaksanakan dalam proses pembelajaran. Yaitu langkah

${ }^{1}$ Isjoni, Pembelajaran Kooperatif Meningkatkan Kecerdasan Komunikasi Antar Peserta Didik (Yogyakarta: Pustaka Pelajar, 2009), 7. 
think (berpikir secara individual), pair (berpasangan dengan teman sebangku), dan share (berbagi jawaban dengan pasangan lain atau seluruh kelas).

\section{B. Rumusan Masalah}

1. Bagaimanakah penerapan model pembelajaran kooperatif tipe TPS (Think Pair Share) pada mata pelajaran Fiqih kelas VII di MTs AlIrsyadiyah Dermolemahbang Sarirejo Lamongan?

2. Bagaimanakah pemahaman siswa pada mata pelajaran Fiqih kelas VII di MTs Al-Irsyadiyah Dermolemahbang Sarirejo Lamongan?

3. Bagaimanakah pengaruh model pembelajaran kooperatif tipe TPS (Think Pair Share) terhadap pemahaman siswa pada mata pelajaran Fiqih kelas VII di MTs Al-Irsyadiyah Dermolemahbang Sarirejo Lamongan?

\section{Metode Penelitian}

Penelitian ini bersifat kuantitatif. Populasi dalam penelitian ini adalah keseluruhan siswa MTs Al Irsyadiyah Dermolemahbang Sarirejo Lamongan. Adapun pengambilan sampel disini, penulis menggunakan teknik proporsional random sampling, yaitu pengambilan sampel yang dilakukan dengan memperhatikan jumlah siswa masing-masing kelas. Adapun pemilihan sampel dilakukan tanpa pandang bulu. ${ }^{2}$ Hal ini dapat dilihat dari pendapatnya Dr. Suharsimi Arikunto: untuk sekedar ancer-ancer, maka apabila kurang dari 100, lebih baik diambil semua sehingga penelitiannya merupakan penelitian populasi, selanjutnya jika subjeknya besar (100 ke atas) maka dapat dikumpulkan $10-15 \%$ atau $20-25 \%$ atau lebih. ${ }^{3}$ Dengan demikian penelitian ini menggunakan penelitian populasi karena subjek yang diteliti adalah kelas VII yang berjumlah 41 siswa.

Teknik pengumpulan datanya dilakukan dengan menggunakan teknik sebagai berikut: Teknik Observasi, Teknik Interview atau wawancara (guru), Teknik Angket (siswa), Dokumentasi. Menurut Suharsimi Arikunto dokumentasi berasal dari kata dokumen yang artinya barang-barang tertulis.

\footnotetext{
${ }^{2}$ Sutrisno Hadi, Metodoligi Reseach, Jilid I (Yogyakarta: Andi Offset, 1980), 75.

${ }^{3}$ Suharsimi Arikunto, Prosedur Penelitian: Suatu Pendekatan Praktik (Jakarta: PT. Rineka Cipta, 2006), 112. 
Di dalam melaksanakan metode dokumentasi peneliti menyelidiki bendabenda tertulis seperti: buku-buku, majalah, dokumen, peraturan-peraturan, notulen, catatan harian, dan sebagainya. ${ }^{4}$

Dalam penelitian ini diperlukan metode analisis data sebagai berikut :

\section{Prosentase}

Metode ini digunakan untuk menjawab rumusan masalah 1 dan 2, yaitu untuk mengetahui penerapan pembelajaran kooperatif tipe TPS (Think Pair Share) dan pemahaman siswa pada mata pelajaran Fiqih, dengan rumus :

$\mathrm{P}=\frac{F}{N} \times 100 \%$

$\mathrm{P}=$ Angka prosentase

$\mathrm{F}=$ Frekuensi

$\mathrm{N}=$ Jumlah individu. ${ }^{5}$

Selanjutnya untuk menafsirkan hasil perhitungan hasil prosentase, penulis menetapkan standar sebagai berikut:

$>\quad 65 \%-100 \%$ : Tergolong Baik

$>\quad 35 \%-65 \% \quad:$ Tergolong Cukup

$>\quad 20 \%-35 \% \quad:$ Tergolong Kurang

$>\quad$ kurang dari $20 \% \quad$ : Tergolong Tidak Baik

\section{Product Moment}

$$
\operatorname{Rxy}=\frac{N \sum x y-\left(\sum x\right)\left(\sum y\right)}{\sqrt{\left\{\left(N \sum x^{2}\right)-\left(\sum x\right)^{2}\right\}\left\{\left(N \sum y^{2}\right)-\left(\sum y\right)^{2}\right\}}}
$$

Rxy : angka indeks korelasi " $r$ " Product Moment

$\mathrm{N}$ : jumlah subyek yang diteliti

$\sum x y:$ jumlah perkalian antara skor $\mathrm{x}$ dan $\mathrm{y}$

$\sum x$ : jumlah nilai variabel $\mathrm{x}$

$\sum y \quad$ : jumlah nilai variabel $\mathrm{y}^{6}$

${ }^{4}$ Suharsimi Arikunto, Prosedur Penelitian suatu Pendekatan Praktek, 135.

5 Anas Sudijono, Pengantar Statistik Pendidikan (Jakarta: Raja Grafindo Persada, 2008), 206.

${ }^{6}$ Anas Sudijono, Pengantar Statistik Pendidikan, 206. 
Siti Mukhoyyaroh \& Syaiful Jazil

\section{Hasil Penelitian}

\section{Penyajian Data Observasi}

Untuk data hasil observasi tentang pelaksanaan model pembelajaran kooperatif tipe TPS (Think Pair Share) penulis lakukan pada saat proses belajar berlangsung dan diperoleh sebagai berikut:

\begin{tabular}{|c|c|c|c|c|c|}
\hline \multirow[b]{2}{*}{ No } & \multirow[b]{2}{*}{ Aspek yang diamati } & \multicolumn{4}{|c|}{ Penilaian } \\
\hline & & 1 & 2 & 3 & 4 \\
\hline 1 & $\begin{array}{l}\text { Antusian siswa terhadap pelajaran } \\
\text { a. Semangat } \\
\text { b. Biasa } \\
\text { c. Malas }\end{array}$ & & & $\sqrt{ }$ & $\sqrt{ }$ \\
\hline 2 & $\begin{array}{l}\text { Respon siswa pada materi } \\
\text { a. Bertanya } \\
\text { b. Menanggapi } \\
\text { c. Diam }\end{array}$ & & $\sqrt{ }$ & $\sqrt{ }$ & $\sqrt{ }$ \\
\hline 3 & $\begin{array}{l}\text { Pengulangan materi setelah penjelasan } \\
\text { a. Diskusi } \\
\text { b. Membaca kembali }\end{array}$ & & $\sqrt{ }$ & $\begin{array}{l}\sqrt{ } \\
\sqrt{ }\end{array}$ & \\
\hline 4 & Persiapan terhaddap sumber atau alatt pendukung & & & & $\sqrt{ }$ \\
\hline 5 & $\begin{array}{l}\text { Pengembangan materi } \\
\text { a. Menyampaikan kepada orang lain } \\
\text { b. Menerapkan dalam keseharian } \\
\text { c. Menerapkan dan menyampaikan kepada } \\
\text { orang lain }\end{array}$ & & $\begin{array}{l}\sqrt{ } \\
\sqrt{ }\end{array}$ & $\sqrt{ }$ & \\
\hline 6 & $\begin{array}{l}\text { Kegiatan akhir setelah penjelasan materi } \\
\text { a. Merangkum } \\
\text { b. Mengerjakan soal } \\
\text { c. Membaca kembali }\end{array}$ & & & $\sqrt{ }$ & $\sqrt{ }$ \\
\hline
\end{tabular}


Keterangan :

a. Nilai 1 kurang baik, bila yang melakukan berjumlah $<25 \%$ dari jumlah siswa.

b. Nilai 2 cukup baik, bila yang melakukan antara 25\% - 50\% dari jumlah siswa.

c. Nilai 3 baik, bila yang melakukan antara 50\% - 75\% dari jumlah siswa.

d. Nilai 4 sangat baik, bila yang melakukan berjumlah $>75 \%$ dari jumlah siswa.

Dari hasil observasi yang diperoleh bahwa kegiatan yang dilakukan guru dapat menempatkan posisinya sesuai profesinya. Di mana guru memberiikan kebebasan kepada siswa untuk mengelola informasi yang telah disampaikan dan sumber-sumber yyang dapat digunakan. Diiperoleh hasil dari proses belajar lebih 75\% jumlah siswa antusias terhadap pelajaran. Hal ini ditunjukkan dengan semangat siswa, respon siswa pada mata pelajaran tergolong baik, hal ini dilihat dari 50\% - 75\% jumlah siswa yang bertanya dan menanggapi penje;asan, pengulangan materi setelah penjelasan tergolong sangat baik hal ini dilihat dari siswa yang diskusi sebanyak 75\% jumlah siswa dan membaca kembali 50\% - 75\%. Persiapan terhadap sumber atau alat pendukung sebesar $75 \%$ jumlah siswa yang melakukan, pengembangan materi menyampaikan kepada orang lain 25\% - 50\% jumlah siswa, menerapkan dalam keseharian sebesar 50\% - 75\% jumlah siswa, menerapkan dan menyampaikan kepada orang lain 25\% - 50\% jumlah siswa pada kegiatan akhir setelah penjelasan materi merangkum mengerjakan soal membaca kembali sebesar 50\% - 75\% jumlah siswa yang tergolong baik.

\section{Penyajian Data Interview}

Dalam wawancara ini yang menjadi responden adalah siswa siswi kelas VII MTs Al-Irsyadiyah. Dimana diperoleh hasiil bahwasanya dengan penggunaan model pembelajaran yang mereka gunakan merupakan langkah-langkah belajar siswa yang dapat mengotrol dirinya dan mengembangkan pikirannya. 


\section{Penyajian Data Angket}

Untuk menunjang dalam kegiatan penyajian data dari hasil penelitian mengenai pengaruh model pembelajaran kooperatif tipe TPS (Think Pair Share) terhadap pemahaman siswa pada mata pelajaran Fiqih kelas VII di MTs Al-Irsyadiyah Dermolemahbang Sarirejo Lamongan, maka peneliti mencari data tentang pengaruh model pembelajaran kooperatif tipe TPS (Think Pair Share) dan juga tentang pemahaman siswa.

Dalam penyajian data ini akan disajikan data yaitu:

\section{Data tentang Pengaruh Model Pembelajaran Kooperatif Tipe TPS (Think Pair Share)}

Adapun untuk format penilaian data hasil angket, peneliti menggunakan skala 1 sampai 3 yang berarti:

1) Pilihan ya, nilai 3

2) Pilihan kadang-kadang, nilai 2

3) Pilihan tidak, nilai 1

Selanjutnya peneliti menyajikan data hasil angket mengenai model pembelajaran TPS (Think Pair Share) yang meliputi kisikisi pembuatan angket yang dapat dilihat dalam lampiran. Dalam mengumpulkan data model pembelajaran TPS (Think Pair Share), peneliti melakukan penyebaran angket kepada siswa dengan cara memilih salah satu jawaban yang sudah tersedia. Adapun data hasil observasi tentang model pembelajaran TPS (Think Pair Share) MTs Al-Irsyadiyah adalah sebagai berikut: 
Skor Hasil Angket Tentang

Pembelajaran Kooperatif Tipe TPS (Think Pair Share)

\begin{tabular}{|c|l|c|c|c|c|c|c|c|c|c|c|c|}
\hline \multirow{2}{*}{ No No } & \multicolumn{10}{|c|}{} & \multicolumn{10}{|c|}{ Item soal } & \multirow{2}{*}{ Jml } \\
\cline { 3 - 10 } & & 1 & 2 & 3 & 4 & 5 & 6 & 7 & 8 & 9 & 10 & \\
\hline 1 & Ahmad Haris Hamzah & 3 & 3 & 3 & 3 & 2 & 1 & 2 & 2 & 3 & 3 & 23 \\
\hline 2 & Ahmad Khabib & 1 & 2 & 2 & 3 & 3 & 3 & 3 & 3 & 3 & 3 & 26 \\
\hline 3 & Ahmad Munawir & 3 & 2 & 3 & 3 & 3 & 2 & 3 & 3 & 3 & 3 & 28 \\
\hline 4 & Ahmad Rudini & 2 & 3 & 3 & 2 & 2 & 3 & 1 & 2 & 3 & 3 & 24 \\
\hline 5 & Alfiyan Fitroni & 1 & 3 & 3 & 3 & 3 & 3 & 3 & 3 & 3 & 3 & 28 \\
\hline 6 & Eko Wahyudi & 3 & 3 & 3 & 3 & 3 & 3 & 3 & 3 & 3 & 3 & 30 \\
\hline 7 & Imron Hamzah & 2 & 3 & 3 & 2 & 3 & 3 & 3 & 3 & 3 & 3 & 26 \\
\hline 8 & Isma'il & 2 & 1 & 2 & 3 & 3 & 2 & 3 & 3 & 1 & 3 & 23 \\
\hline 9 & Karomatul Auliya' & 2 & 3 & 3 & 2 & 3 & 2 & 1 & 3 & 3 & 3 & 25 \\
\hline 10 & Luluk Fauziah & 3 & 1 & 3 & 3 & 3 & 2 & 2 & 3 & 3 & 3 & 26 \\
\hline 11 & Muhammad Mukhlis & 2 & 2 & 3 & 3 & 3 & 3 & 2 & 1 & 3 & 3 & 25 \\
\hline 12 & Muhammad Rois & 1 & 3 & 3 & 3 & 3 & 3 & 3 & 2 & 3 & 3 & 27 \\
\hline 13 & Abdullah Khoiri & 2 & 3 & 3 & 3 & 3 & 3 & 3 & 3 & 3 & 3 & 29 \\
\hline 14 & Siti Mutmainnah & 3 & 3 & 3 & 3 & 3 & 3 & 3 & 2 & 3 & 3 & 29 \\
\hline 15 & Zakiyatul Fikriyah S & 1 & 3 & 3 & 3 & 3 & 3 & 3 & 2 & 3 & 3 & 27 \\
\hline 16 & Ahmad Fadholi & 3 & 3 & 3 & 3 & 3 & 3 & 3 & 3 & 3 & 3 & 30 \\
\hline 17 & Ahmad Khafidlul Am & 3 & 2 & 3 & 2 & 3 & 3 & 1 & 3 & 3 & 3 & 26 \\
\hline 18 & Ahmad Rubiyanto & 2 & 3 & 3 & 3 & 3 & 2 & 3 & 2 & 1 & 3 & 25 \\
\hline 19 & Ahmad Syifauddin & 1 & 3 & 3 & 3 & 3 & 3 & 3 & 2 & 3 & 3 & 27 \\
\hline 20 & Abd. Majid & 3 & 3 & 3 & 3 & 3 & 3 & 3 & 3 & 3 & 3 & 30 \\
\hline 21 & Aris Ikhya' Ulumuddin & 3 & 3 & 3 & 3 & 3 & 3 & 3 & 3 & 3 & 3 & 30 \\
\hline 22 & Asmaul Fauziyah & 1 & 3 & 3 & 3 & 3 & 3 & 3 & 3 & 3 & 3 & 28 \\
\hline 23 & Dia Kumala Sari & 2 & 3 & 3 & 3 & 3 & 3 & 3 & 3 & 3 & 3 & 29 \\
\hline 24 & Eka Pratiwi Ningsih & 3 & 3 & 3 & 3 & 3 & 3 & 3 & 3 & 3 & 3 & 30 \\
\hline 25 & Faizatur Rohmi & 1 & 3 & 3 & 3 & 3 & 3 & 3 & 3 & 3 & 3 & 28 \\
\hline 26 & Fitriya Anggraini & 2 & 2 & 3 & 3 & 3 & 3 & 3 & 2 & 3 & 3 & 27 \\
\hline 27 & Habibah & 2 & 3 & 3 & 3 & 2 & 3 & 3 & 2 & 3 & 2 & 26 \\
\hline 28 & Heru Mulyadi & 2 & 3 & 3 & 2 & 2 & 3 & 2 & 3 & 2 & 3 & 25 \\
\hline 29 & Kusairi & 2 & 3 & 3 & 3 & 3 & 3 & 3 & 1 & 3 & 3 & 27 \\
\hline 30 & Lailatul Munfa'ati & 2 & 3 & 3 & 3 & 3 & 3 & 3 & 2 & 3 & 3 & 28 \\
\hline 31 & M. Zaki Fuad & 2 & 3 & 2 & 2 & 3 & 3 & 1 & 3 & 2 & 3 & 24 \\
\hline
\end{tabular}


Siti Mukhoyyaroh \& Syaiful Jazil

\begin{tabular}{|l|l|l|l|l|l|l|l|l|l|l|l|l|}
\hline 32 & SM. Azki Hifni Firdaus & 1 & 3 & 3 & 3 & 3 & 3 & 3 & 3 & 3 & 3 & 28 \\
\hline 33 & M. Nuris Syahroni & 1 & 3 & 3 & 3 & 3 & 3 & 3 & 3 & 3 & 3 & 28 \\
\hline 34 & M. Udin & 3 & 3 & 3 & 3 & 3 & 3 & 3 & 3 & 3 & 3 & 30 \\
\hline 35 & M. Shokib & 2 & 3 & 3 & 3 & 3 & 3 & 3 & 3 & 3 & 3 & 29 \\
\hline 36 & Nur Fatmawati & 1 & 3 & 3 & 3 & 3 & 3 & 3 & 3 & 3 & 3 & 28 \\
\hline 37 & Sujiono & 3 & 3 & 3 & 3 & 3 & 3 & 3 & 3 & 3 & 3 & 30 \\
\hline 38 & Sofyan Asrori & 3 & 3 & 3 & 3 & 3 & 3 & 3 & 3 & 3 & 3 & 30 \\
\hline 39 & Siti Miftahul Fitriani & 3 & 3 & 3 & 3 & 3 & 3 & 3 & 3 & 3 & 3 & 30 \\
\hline 40 & Thoifur Rohman & 2 & 3 & 3 & 3 & 3 & 3 & 3 & 3 & 3 & 3 & 29 \\
\hline 41 & Ulin Nihayatul Q & 3 & 3 & 3 & 3 & 3 & 3 & 3 & 3 & 3 & 3 & 30 \\
\hline
\end{tabular}

Dari tabel diatas, peneliti akan memprosentasikan dari masingmasing item pertanyaan dari pada angket, yakni sebagai berikut:

Prosentase tentang guru Fiqih pernah menggunakan model pembelajaran kooperatif tipe TPS

\begin{tabular}{|l|l|l|l|l|l|}
\hline No & Nilai & Kategori & N & F & $\%$ \\
\hline 1 & 3 & Ya & 41 & 15 & 36 \\
\hline 2 & 2 & Kadang-kadang & & 16 & 39 \\
\hline 3 & 1 & Tidak & & 10 & 25 \\
\hline \multicolumn{2}{|l|}{ Jumlah } & & 41 & 100 \\
\hline
\end{tabular}

Dari hasil prosentase diatas, bahwa guru Fiqih pernah menggunakan model pembelajaran TPS adalah 36\% berarti "cukup".

Prosentase Tentang Pembelajaran TPS Yang Disajikan Sesuai Dengan Tujuan Pembelajaran

\begin{tabular}{|l|l|l|l|l|l|}
\hline No & Nilai & Kategori & N & F & $\%$ \\
\hline 1 & 3 & Ya & 41 & 34 & 83 \\
\hline 2 & 2 & Kadang-kadang & & 5 & 11 \\
\hline 3 & 1 & Tidak & & 2 & 6 \\
\hline \multicolumn{2}{|l|}{ Jumlah } & & 41 & 100 \\
\hline
\end{tabular}

Dari hasil prosentase diatas, penggunaan pembelajaran TPS yang sesuai dengan tujuan pembelajaran adalah $83 \%$ berarti "baik". 
Prosentase tentang penyesuaian materi terhadap pembelajaran TPS

\begin{tabular}{|l|l|l|l|l|l|}
\hline No & Nilai & Kategori & N & F & $\%$ \\
\hline 1 & 3 & Ya & 41 & 38 & 90 \\
\hline 2 & 2 & Kadang-kadang & & 3 & 10 \\
\hline 3 & 1 & Tidak & & - & - \\
\hline \multicolumn{2}{|l|}{ Jumlah } & & 41 & 100 \\
\hline
\end{tabular}

Dari hasil prosentase diatas, penyesuaian materi terhadap pembelajaran TPS adalah 90\% berarti tergolong "baik".

Prosentase tentang penggunaan pembelajaran TPS bisa meningkatkan motivasi dalam PBM

\begin{tabular}{|l|l|l|l|l|l|}
\hline No & Nilai & Kategori & N & F & $\%$ \\
\hline 1 & 3 & Ya & 41 & 35 & 85 \\
\hline 2 & 2 & Kadang-kadang & & 6 & 15 \\
\hline 3 & 1 & Tidak & & & \\
\hline \multicolumn{2}{|l|}{ Jumlah } & & 41 & 100 \\
\hline
\end{tabular}

Dari hasil prosentase diatas, penggunaan pembelajaran TPS bisa meningkatkan motivasi dalam PBM adalah $85 \%$ berarti "baik".

Prosentase tentang penyajian pembelajaran TPS dapat menarik minat dan perhatian siswa

\begin{tabular}{|l|l|l|l|l|l|}
\hline No & Nilai & Kategori & N & F & $\%$ \\
\hline 1 & 3 & Ya & 41 & 37 & 88 \\
\hline 2 & 2 & Kadang-kadang & & 4 & 12 \\
\hline 3 & 1 & Tidak & & & \\
\hline Jumlah & & 41 & 100 \\
\hline
\end{tabular}

Dari hasil prosentase diatas, bahwa pembelajaran TPS dapat menarik minat dan perhatian siswa adalah $88 \%$ berarti "baik". 
Prosentase tentang penggunaan pembelajaran TPS pada siswa akan merasa senang dan tidak bosan

\begin{tabular}{|l|l|l|l|l|l|}
\hline No & Nilai & Kategori & N & F & $\%$ \\
\hline 1 & 3 & Ya & 41 & 35 & 85 \\
\hline 2 & 2 & Kadang-kadang & & 5 & 12 \\
\hline 3 & 1 & Tidak & & 1 & 3 \\
\hline Jumlah & & 41 & 100 \\
\hline
\end{tabular}

Dari hasil prosentase diatas, penggunaan pembelajaran TPS akan bertambah senang dan tidak bosan adalah $85 \%$ berarti tergolong "baik"

Prosentase tentang penggunaan pembelajaran TPS pelajaran mudah diingat

\begin{tabular}{|l|l|l|l|l|l|}
\hline No & Nilai & Kategori & N & F & $\%$ \\
\hline 1 & 3 & Ya & 41 & 33 & 80 \\
\hline 2 & 2 & Kadang-kadang & & 4 & 10 \\
\hline 3 & 1 & Tidak & & 4 & 10 \\
\hline Jumlah & & 41 & 100 \\
\hline
\end{tabular}

Dari hasil prosentase diatas, penggunaan pembelajaran TPS pelajaran mudah diingat adalah $80 \%$ berarti tergolong "baik".

Prosentase tentang penggunaan pembelajaran TPS suasana kelas menjadi tenang atau tidak

\begin{tabular}{|l|l|l|l|l|l|}
\hline No & Nilai & Kategori & N & F & $\%$ \\
\hline 1 & 3 & Ya & 41 & 29 & 70 \\
\hline 2 & 2 & Kadang-kadang & & 10 & 24 \\
\hline 3 & 1 & Tidak & & 2 & 6 \\
\hline \multicolumn{2}{|l|}{ Jumlah } & & 41 & 100 \\
\hline
\end{tabular}

Dari hasil prosentase diatas, penggunaan pembelajaran TPS suasana kelas akan menjadi tenang adalah $70 \%$ berarti tergolong "baik". 
Prosentase tentang guru dalam menyampaikan materi dengan menggunakan TPS akan mudah dimengerti

\begin{tabular}{|l|l|l|l|l|l|}
\hline No & Nilai & Kategori & N & F & $\%$ \\
\hline 1 & 3 & Ya & 41 & 37 & 88 \\
\hline 2 & 2 & Kadang-kadang & & 2 & 6 \\
\hline 3 & 1 & Tidak & & 2 & 6 \\
\hline \multicolumn{2}{|l}{ Jumlah } & & 41 & 100 \\
\hline
\end{tabular}

Dari hasil prosentase diatas, bahwa penggunaan pembelajaran TPS pada siswa akan mudah dimengerti adalah $88 \%$ berarti tergolong "baik".

Prosentase tentang pelajaran yang dicapai maksimal dengan menggunakan pembelajaran TPS

\begin{tabular}{|l|l|l|l|l|l|}
\hline No & Nilai & Kategori & N & F & $\%$ \\
\hline 1 & 3 & Ya & 41 & 40 & 97 \\
\hline 2 & 2 & Kadang-kadang & & 1 & 3 \\
\hline 3 & 1 & Tidak & & - & - \\
\hline \multicolumn{2}{|l}{ Jumlah } & & 41 & 100 \\
\hline
\end{tabular}

Dari hasil prosentase diatas, bahwa pelajaran yang dicapai maksimal dengan menggunakan pembelajaran TPS adalah 97\% berarti tergolong "baik".

\section{Data tentang Pemahaman Siswa pada Mata Pelajaran} Fiqih

Untuk mengetahui data tentang pemahaman siswa menggunakan angket yang pengambilannya mengacu pada kisikisi angket yang juga dilihat dalam lampiran.

Untuk mengetahui pemahaman siswa kelas VII di MTs Al Irsyadiyah ini, maka peneliti akan menyajikan data hasil angket ke dalam tabel. 
Siti Mukhoyyaroh \& Syaiful Jazil

Skor Hasil Angket Tentang

Pemahaman siswa MTs Al Irsyadiyah

\begin{tabular}{|c|l|c|c|c|c|c|c|c|c|c|c|c|}
\hline \multirow{2}{*}{ No } & \multicolumn{10}{|c|}{ Nama } & \multicolumn{10}{|c|}{ Item soal } & \multirow{2}{*}{ Jml } \\
\cline { 2 - 11 } & & 1 & 2 & 3 & 4 & 5 & 6 & 7 & 8 & 9 & 10 & \\
\hline 1 & Ahmad Haris Hamzah & 2 & 2 & 2 & 3 & 3 & 2 & 2 & 3 & 3 & 3 & 25 \\
\hline 2 & Ahmad Khabib & 2 & 3 & 2 & 2 & 3 & 3 & 1 & 1 & 2 & 3 & 22 \\
\hline 3 & Ahmad Munawir & 2 & 1 & 3 & 3 & 3 & 3 & 3 & 3 & 3 & 3 & 27 \\
\hline 4 & Ahmad Rudini & 2 & 1 & 3 & 3 & 3 & 3 & 3 & 3 & 3 & 3 & 27 \\
\hline 5 & Alfiyan Fitroni & 3 & 2 & 3 & 2 & 3 & 2 & 2 & 3 & 2 & 3 & 25 \\
\hline 6 & Eko Wahyudi & 2 & 3 & 2 & 3 & 3 & 2 & 3 & 2 & 3 & 3 & 26 \\
\hline 7 & Imron Hamzah & 2 & 3 & 2 & 3 & 3 & 3 & 2 & 3 & 3 & 2 & 26 \\
\hline 8 & Isma'il & 3 & 3 & 3 & 3 & 3 & 2 & 3 & 2 & 3 & 3 & 28 \\
\hline 9 & Karomatul Auliya' & 2 & 3 & 2 & 3 & 3 & 3 & 2 & 3 & 2 & 3 & 26 \\
\hline 10 & Luluk Fauziah & 3 & 2 & 3 & 3 & 3 & 2 & 3 & 2 & 3 & 3 & 27 \\
\hline 11 & Muhammad Mukhlis & 2 & 3 & 2 & 3 & 3 & 3 & 3 & 3 & 2 & 3 & 27 \\
\hline 12 & Muhammad Rois & 3 & 2 & 3 & 3 & 3 & 3 & 2 & 3 & 2 & 3 & 27 \\
\hline 13 & Abdullah Khoiri & 2 & 3 & 2 & 3 & 3 & 2 & 3 & 3 & 2 & 3 & 26 \\
\hline 14 & Siti Mutmainnah & 3 & 2 & 3 & 2 & 3 & 3 & 3 & 2 & 2 & 3 & 26 \\
\hline 15 & Zakiyatul Fikriyah S & 3 & 1 & 2 & 2 & 3 & 3 & 2 & 3 & 2 & 3 & 24 \\
\hline 16 & Ahmad Fadholi & 3 & 2 & 3 & 2 & 3 & 3 & 3 & 3 & 3 & 3 & 28 \\
\hline 17 & Ahmad Khafidlul Am & 2 & 2 & 3 & 2 & 3 & 3 & 2 & 3 & 2 & 3 & 25 \\
\hline 18 & Ahmad Rubiyanto & 2 & 3 & 2 & 3 & 3 & 3 & 2 & 3 & 2 & 3 & 26 \\
\hline 19 & Ahmad Syifauddin & 2 & 3 & 2 & 2 & 3 & 3 & 2 & 3 & 2 & 3 & 25 \\
\hline 20 & Abd. Majid & 2 & 3 & 2 & 3 & 3 & 3 & 2 & 2 & 3 & 3 & 26 \\
\hline 21 & Aris Ikhya' Ulumuddin & 3 & 3 & 2 & 3 & 3 & 3 & 1 & 2 & 3 & 3 & 26 \\
\hline 22 & Asmaul Fauziyah & 3 & 3 & 3 & 3 & 3 & 3 & 2 & 2 & 2 & 3 & 27 \\
\hline 23 & Dia Kumala Sari & 3 & 2 & 3 & 3 & 2 & 1 & 3 & 3 & 3 & 3 & 26 \\
\hline 24 & Eka Pratiwi Ningsih & 3 & 3 & 2 & 3 & 3 & 3 & 3 & 3 & 2 & 3 & 28 \\
\hline 25 & Faizatur Rohmi & 3 & 2 & 3 & 2 & 3 & 3 & 3 & 2 & 3 & 3 & 27 \\
\hline 26 & Fitriya Anggraini & 2 & 3 & 2 & 2 & 3 & 3 & 3 & 3 & 2 & 3 & 26 \\
\hline 27 & Habibah & 2 & 2 & 3 & 2 & 3 & 3 & 2 & 3 & 3 & 3 & 26 \\
\hline 28 & Heru Mulyadi & 2 & 2 & 3 & 3 & 3 & 3 & 3 & 2 & 2 & 3 & 26 \\
\hline 29 & Kusairi & 3 & 2 & 3 & 3 & 3 & 3 & 2 & 2 & 2 & 3 & 26 \\
\hline 30 & Lailatul Munfa'ati & 3 & 3 & 2 & 2 & 3 & 3 & 3 & 3 & 2 & 3 & 27 \\
\hline
\end{tabular}

Jurnal Pendidikan Agama Islam

Volume 01 Nomor 01 Mei 2013

Hal 34 - 44 
Pengaruh Model Pembelajaran Kooperatif Tipe TPS

\begin{tabular}{|l|l|l|l|l|l|l|l|l|l|l|l|l|}
\hline 31 & M. Zaki Fuad & 3 & 3 & 3 & 2 & 3 & 3 & 2 & 3 & 3 & 3 & 28 \\
\hline 32 & M. Azki Hifni Firdaus & 3 & 3 & 3 & 3 & 3 & 3 & 3 & 3 & 3 & 3 & 30 \\
\hline 33 & M. Nuris Syahroni & 3 & 2 & 3 & 3 & 3 & 3 & 2 & 3 & 3 & 3 & 28 \\
\hline 34 & M. Udin & 3 & 3 & 3 & 3 & 3 & 3 & 3 & 2 & 2 & 3 & 28 \\
\hline 35 & M. Shokib & 3 & 2 & 3 & 3 & 3 & 3 & 2 & 3 & 3 & 3 & 28 \\
\hline 36 & Nur Fatmawati & 3 & 3 & 3 & 3 & 3 & 3 & 2 & 3 & 2 & 3 & 28 \\
\hline 37 & Sujiono & 3 & 2 & 3 & 3 & 3 & 3 & 3 & 3 & 3 & 3 & 29 \\
\hline 38 & Sofyan Asrori & 3 & 3 & 3 & 3 & 3 & 3 & 2 & 3 & 2 & 3 & 28 \\
\hline 39 & Siti Miftahul Fitriani & 3 & 3 & 3 & 3 & 3 & 3 & 3 & 3 & 3 & 3 & 30 \\
\hline 40 & Thoifur Rohman & 3 & 3 & 3 & 3 & 3 & 3 & 3 & 3 & 3 & 3 & 30 \\
\hline 41 & Ulin Nihayatul Q & 3 & 3 & 3 & 3 & 3 & 3 & 3 & 3 & 3 & 3 & 30 \\
\hline
\end{tabular}

Dari tabel di atas, peneliti akan memprosentasikan dari masing-masing item pertanyaan dari angket, yakni sebagai berikut :

Prosentase Tentang menjelaskan kembali setelah guru menyampaikan

\begin{tabular}{|l|l|l|l|l|l|}
\hline No & Nilai & Kategori & N & F & $\%$ \\
\hline 1 & 3 & Ya & 41 & 25 & 61 \\
\hline 2 & 2 & Kadang-kadang & & 16 & 39 \\
\hline 3 & 1 & Tidak & & & \\
\hline \multicolumn{2}{|l|}{ Jumlah } & & & 100 \\
\hline
\end{tabular}

Dari hasil prosentase diatas, bahwa 61\% (ya) siswa mampu menjelaskan kembali setelah guru menyampaikan pelajaran.

Prosentase Tentang jika paham materi, maka materi selalu diingat

\begin{tabular}{|l|l|l|l|l|l|}
\hline No & Nilai & Kategori & N & F & $\%$ \\
\hline 1 & 3 & Ya & 41 & 23 & 56 \\
\hline 2 & 2 & Kadang-kadang & & 25 & 39 \\
\hline 3 & 1 & Tidak & & 3 & 5 \\
\hline Jumlah & & & 100 \\
\hline
\end{tabular}


Dari hasil prosentase diatas, bahwa 56\% (ya) siswa selalu ingat dengan materi jika materi yang disampaikan paham.

Prosentase Tentang siswa mampu menyimpulkan kembali materi yang disampaikan guru

\begin{tabular}{|l|l|l|l|l|l|}
\hline No & Nilai & Kategori & N & F & $\%$ \\
\hline 1 & 3 & Ya & 41 & 26 & 63 \\
\hline 2 & 2 & Kadang-kadang & & 15 & 37 \\
\hline 3 & 1 & Tidak & & & \\
\hline \multicolumn{2}{|l|}{ Jumlah } & & & 100 \\
\hline
\end{tabular}

Dari hasil prosentase diatas, bahwa 63\% siswa mampu menyimpulkan kembali materi yang disampaikan guru.

Prosentase Tentang perasaan senang jika pelajaran yang disampaikan paham

\begin{tabular}{|l|l|l|l|l|l|}
\hline No & Nilai & Kategori & N & F & $\%$ \\
\hline 1 & 3 & Ya & 41 & 29 & 70 \\
\hline 2 & 2 & Kadang-kadang & & 12 & 30 \\
\hline 3 & 1 & Tidak & & & \\
\hline Jumlah & & & 100 \\
\hline
\end{tabular}

Dari hasil prosentase diatas, bahwa $70 \%$ (ya) siswa merasa senang jika pelajaran yang disampaikaan paham.

Prosentase Tentang perasaan siswa puas jika materi yang disampaikan paham

\begin{tabular}{|l|l|l|l|l|l|}
\hline No & Nilai & Kategori & N & F & $\%$ \\
\hline 1 & 3 & Ya & 41 & 40 & 97 \\
\hline 2 & 2 & Kadang-kadang & & 1 & 3 \\
\hline 3 & 1 & Tidak & & - & - \\
\hline \multicolumn{2}{|l|}{ Jumlah } & & & 100 \\
\hline
\end{tabular}

Dari hasil prosentase diatas, bahwa 97\% (ya) siswa merasa puas jika materi yang disampaikan paham. 
Prosentase Tentang keberanian siswa maju ke depan untuk menerangkan kembali pelajaran yang telah disampaikan guru

\begin{tabular}{|l|l|l|l|l|l|}
\hline No & Nilai & Kategori & N & F & $\%$ \\
\hline 1 & 3 & Ya & 41 & 34 & 83 \\
\hline 2 & 2 & Kadang-kadang & & 6 & 14 \\
\hline 3 & 1 & Tidak & & 1 & 3 \\
\hline \multicolumn{2}{|l|}{ Jumlah } & & & 100 \\
\hline
\end{tabular}

Dari hasil prosentase diatas, bahwa keberanian siswa maju ke depan untuk menerangkan kembali pelajaran yang disampaikan guru adalah $83 \%$ tergolong "baik".

Prosentase Tentang siswa mampu mempraktekkan kembali pelajaran yang disampaikan

\begin{tabular}{|l|l|l|l|l|l|}
\hline No & Nilai & Kategori & N & F & $\%$ \\
\hline 1 & 3 & Ya & 41 & 21 & 51 \\
\hline 2 & 2 & Kadang-kadang & & 18 & 43 \\
\hline 3 & 1 & Tidak & & 2 & 6 \\
\hline \multicolumn{2}{|l|}{ Jumlah } & & & 100 \\
\hline
\end{tabular}

Dari hasil prosentase diatas, bahwa 51\% (ya) siswa mampu mempraktekkan kembali pelajaran yang disampaikan.

Prosentase Tentang bertanya pada guru jika tidak paham dengan materi

\begin{tabular}{|l|l|l|l|l|l|}
\hline No & Nilai & Kategori & N & F & $\%$ \\
\hline 1 & 3 & Ya & 41 & 29 & 70 \\
\hline 2 & 2 & Kadang-kadang & & 11 & 27 \\
\hline 3 & 1 & Tidak & & 1 & 3 \\
\hline \multicolumn{2}{|l|}{ Jumlah } & & & 100 \\
\hline
\end{tabular}

Dari hasil prosentase diatas, bahwa 70\% (ya) siswa bertanya pada guru jika tidak paham dengan materi. 
Prosentase Tentang siswa menjawab pertanyaan guru jika siswa paham dengan pertanyaannya

\begin{tabular}{|l|l|l|l|l|l|}
\hline No & Nilai & Kategori & N & F & $\%$ \\
\hline 1 & 3 & Ya & 41 & 21 & 51 \\
\hline 2 & 2 & Kadang-kadang & & 20 & 49 \\
\hline 3 & 1 & Tidak & & & \\
\hline \multicolumn{2}{|l|}{ Jumlah } & & & 100 \\
\hline
\end{tabular}

Dari hasil prosentase diatas, bahwa 51\% (ya) menjawab pertanyaan guru jika siswa paham dengan pertanyaannya.

Prosentase Tentang bagus tidaknya hasil ulangan harian jika paham dengan soal yang diujikan

\begin{tabular}{|l|l|l|l|l|l|}
\hline No & Nilai & Kategori & N & F & $\%$ \\
\hline 1 & 3 & Ya & 41 & 40 & 97 \\
\hline 2 & 2 & Kadang-kadang & & 1 & 3 \\
\hline 3 & 1 & Tidak & & - & - \\
\hline \multicolumn{2}{|l|}{ Jumlah } & & & 100 \\
\hline
\end{tabular}

Dari hasil prosentase diatas, bahwa bagus tidaknya hasil ulangan harian jika peham dengan soal yang diujikan adalah 97\% tergolong "baik".

\section{E. Analisis Data}

Dalam menganalisa data yang disajikan di atas, maka peneliti akan menganalisis data tersebut dengan menggunakan dua teknik analisa data, yaitu teknik eksplanatif kuantitatif dengan menggunakan rumus prosentase dan teknik analisa data kuantitatif dengan rumus product moment. Adapun analisanya sebagai berikut :

1. Analisa data yang berhubungan dengan rumusan masalah pertama yaitu tentang model pembelajaran kooperatif TPS (Think Pair Share). Untuk menganalisa tentang penggunaan model pembelajaran TPS ini, peneliti menggunakan rumus prosentase sebagai berikut: 
$\mathrm{P}=\frac{F}{N} \times 100 \%$

$\mathrm{P}=$ Angka prosentase

$\mathrm{F}=$ Frekuensi

$\mathrm{N}=$ Jumlah individu.

Sedangkan untuk menganalisa data hasil perhitungan di atas, maka peneliti menggunakan standar yang berpedoman sebagai berikut :

$\begin{array}{lll}> & 65 \%-100 \% & \text { : tergolong baik } \\ > & 35 \%-65 \% & : \text { tergolong cukup } \\ > & 20 \%-35 \% & : \text { tergolong kurang } \\ > & \text { kurang dari } 20 \% & \text { : tergolong tidak baik }\end{array}$

Adapun untuk mengetahui data tentang model pembelajaran kooperatif tipe TPS (Think Pair Share), penulis menggunakan rumus sebagai berikut :

$$
\begin{aligned}
\mathrm{P} & =\frac{F}{N} \times 100 \% \\
\mathrm{P} & =\frac{\text { Jumlah Frekuensi Skor }}{\text { Banyaknya Soal }} \times 100 \% \\
\mathrm{P} & =\frac{80 \frac{2}{10} \times 100 \%=80,2 \%}{}
\end{aligned}
$$

Jadi dari perhitungan dan jawaban diatas, maka diperoleh data tentang penerapan model pembelajaran kooperatif tipe TPS (Think Pair Share) pada mata pelajaran Fiqih kelas VII dengan alternatif jawaban "ya" sebesar 80,2\% yang berarti masuk dalam kategori baik.

2. Analisa data yang berhubungan dengan rumusan masalah kedua yaitu tentang pemahaman siswa.

Adapun untuk mengetahui data tentang pemahaman siswa, penulis menggunakan rumus sebagai berikut :

$\mathrm{P}=\frac{F}{N} \times 100 \%$ 


$$
\begin{aligned}
& \mathrm{P}=\frac{\text { Jumlah Frekuensi Skor }}{\text { Banyaknya Soal }} \times 100 \% \\
& \mathrm{P}=\frac{699}{10} \times 100 \%=69,9 \%
\end{aligned}
$$

Jadi dari perhitungan dan jawaban diatas, maka diperoleh data tentang pemahaman siswa pada mata pelajaran Fiqih kelas VII dengan alternatif jawaban "ya" sebesar $69,9 \%$ yang berarti masuk dalam kategori baik.

3. Analisa data yang berhubungan dengan dengan rumusan masalah ketiga tentang pengaruh model pembelajaran kooperatif tipe TPS (Think Pair Share) terhadap pemahaman siswa pada mata pelajaran Fiqih kelas VII di MTs Al Irsyadiyah Dermolemahbang Sarirejo Lamonagn.

a. Data Kualitatif

Berdasarkan pada prosentase diatas tentang model pembelajaran kooperatif tipe TPS dan pemahaman siswa kelas VII di MTs Al Irsyadiyah yang peneliti lakukan, maka dapat disimpulkan bahwa model pembelajaran kooperatif tipe TPS pada saat proses belajar mengajar yang telah dilaksanakan,

Adapun tentang pemahaman siswa kelas VII di MTs Al Irsyadiyah adalah tergolong baik.

Namun untuk lebih memperkuat analisis kualitatif ini, peneliti juga menggunakan kuantitatif product moment.

b. Data Kuantitatif Product Moment

Untuk mengetahui ada tidaknya pengaruh antara penggunaan model pembelajaran kooperatif tipe TPS terhadap pemahaman siswa kelas VII di MTs Al Irsyadiyah Dermolemahbang Sarirejo Lamongan, maka peneliti menggunakan rumus product moment sebagai berikut :

$$
\operatorname{Rxy}=\frac{N \sum x y-\left(\sum x\right)\left(\sum y\right)}{\sqrt{\left\{\left(N \sum x^{2}\right)-\left(\sum x\right)^{2}\right\}\left\{\left(N \sum y^{2}\right)-\left(\sum y\right)^{2}\right\}}}
$$


Adapun langkah selanjutnya dalam mencari korelasi antara variabel X (model pembelajaran kooperatif tipe TPS) dengan variabel Y (pemahaman siswa) adalah dengan menyiapkan tabel kerja perhitungan sebagai berikut:

Tabel Kerja Korelasi Product Moment

\begin{tabular}{|c|c|c|c|c|c|}
\hline No & X & $\mathrm{Y}$ & $\mathrm{Xy}$ & $\mathrm{X}^{2}$ & $\mathrm{Y}^{2}$ \\
\hline 1 & 23 & 25 & 575 & 529 & 625 \\
\hline 2 & 26 & 22 & 572 & 676 & 484 \\
\hline 3 & 28 & 27 & 756 & 784 & 729 \\
\hline 4 & 24 & 27 & 648 & 576 & 729 \\
\hline 5 & 28 & 25 & 700 & 784 & 625 \\
\hline 6 & 30 & 26 & 780 & 900 & 676 \\
\hline 7 & 26 & 26 & 676 & 676 & 676 \\
\hline 8 & 23 & 28 & 644 & 529 & 784 \\
\hline 9 & 25 & 26 & 650 & 625 & 676 \\
\hline 10 & 26 & 27 & 702 & 676 & 729 \\
\hline 11 & 25 & 27 & 675 & 625 & 729 \\
\hline 12 & 27 & 27 & 729 & 729 & 729 \\
\hline 13 & 29 & 26 & 754 & 841 & 676 \\
\hline 14 & 29 & 26 & 754 & 841 & 676 \\
\hline 15 & 27 & 24 & 648 & 729 & 576 \\
\hline 16 & 30 & 28 & 840 & 900 & 784 \\
\hline 17 & 26 & 25 & 650 & 676 & 625 \\
\hline 18 & 25 & 26 & 650 & 625 & 676 \\
\hline 19 & 27 & 25 & 675 & 729 & 625 \\
\hline 20 & 30 & 26 & 780 & 900 & 676 \\
\hline 21 & 30 & 26 & 780 & 900 & 676 \\
\hline 22 & 28 & 27 & 756 & 784 & 729 \\
\hline 23 & 29 & 26 & 754 & 841 & 676 \\
\hline 24 & 30 & 28 & 840 & 900 & 784 \\
\hline 25 & 28 & 27 & 756 & 784 & 729 \\
\hline 26 & 27 & 26 & 702 & 729 & 676 \\
\hline 27 & 26 & 26 & 676 & 676 & 676 \\
\hline 28 & 25 & 26 & 725 & 625 & 676 \\
\hline
\end{tabular}


Siti Mukhoyyaroh \& Syaiful Jazil

\begin{tabular}{|l|c|c|c|c|c|}
\hline 29 & 27 & 26 & 702 & 729 & 676 \\
\hline 30 & 28 & 27 & 756 & 784 & 729 \\
\hline 31 & 24 & 28 & 840 & 576 & 784 \\
\hline 32 & 28 & 30 & 840 & 784 & 900 \\
\hline 33 & 28 & 28 & 784 & 784 & 784 \\
\hline 34 & 30 & 28 & 840 & 900 & 784 \\
\hline 35 & 29 & 28 & 812 & 841 & 784 \\
\hline 36 & 28 & 28 & 784 & 784 & 784 \\
\hline 37 & 30 & 29 & 870 & 900 & 841 \\
\hline 38 & 30 & 28 & 840 & 900 & 784 \\
\hline 39 & 30 & 30 & 900 & 900 & 900 \\
\hline 40 & 29 & 30 & 870 & 841 & 900 \\
\hline 41 & 30 & 30 & 900 & 900 & 900 \\
\hline & $\sum \mathrm{x}=1.12$ & $\sum \mathrm{y}=1.101$ & $\sum \mathrm{xy}=30.585$ & $\sum \mathrm{x}^{2}=31.212$ & $\sum \mathrm{y}^{2}=29.677$ \\
& 8 & & & & \\
\hline
\end{tabular}

$$
\begin{array}{lll}
\text { Diket }: & \sum x=1.128 & \sum x^{2}=31.212 \\
& \sum y=1.101 & \sum y^{2}=29.677 \\
& \sum x y=30.585 &
\end{array}
$$

Dari tabel perhitungan tersebut, langkah selanjutnya adalah memasukkan data ke dalam rumus product moment berikut ini :

$$
\begin{aligned}
& \mathrm{r}_{\mathrm{xy}}=\frac{N \sum x y-\left(\sum x\right)\left(\sum y\right)}{\sqrt{\left\{\left(N \sum x^{2}\right)-\left(\sum x\right)^{2}\right\}\left\{\left(N \sum y^{2}\right)-\left(\sum y\right)^{2}\right\}}} \\
& \mathrm{r}_{\mathrm{xy}}=\frac{41 x 30.585-(1.128)(1.101)}{\sqrt{\left\{(41 x 31.212)-(1.128)^{2}\right\}\left\{(41 x 29.677)-(1.101)^{2}\right\}}} \\
& \mathrm{r}_{\mathrm{xy}}=\frac{1.253 .985-1.241 .928}{\sqrt{\{(1.279 .692)-(1.272 .384)\}\{(1.216 .757)-(1.212 .201)\}}} \\
& \mathrm{r}_{\mathrm{xy}}=\frac{12057}{\sqrt{(7308)(4556)}}
\end{aligned}
$$




$$
\begin{aligned}
& r_{x y}=\frac{12057}{\sqrt{33295248}} \\
& r_{x y}=\frac{12057}{57702034} \\
& r_{x y}=0,208
\end{aligned}
$$

Untuk menguji kebenaran hipotesis adalah dengan mengkonsultasikan hasil perhitungan rxy dengan nilai $\mathrm{r}$ pada tabel koefisien korelasi " $\mathrm{r}$ " Product Moment. Namun terlebih dahulu dicari derajat bebasnya $(\mathrm{db} / \mathrm{df})$ dengan rumus $\mathrm{db} / \mathrm{df}=\mathrm{N}-2=41-2=$ 39. Kemudian db/df tersebut dinilai pada tabel " $\mathrm{r}$ " product moment yang menunjukkan bahwa taraf signifikansi $5 \%$ diperoleh $\mathrm{r}$ tabel 0,316 , sedangkan pada taraf signifikansi $1 \%$ diperoleh tabel $=0,408$.

Dengan demikian dapat diketahui bahwa $\mathrm{r}_{\mathrm{xy}}<\mathrm{r}$ tabel pada taraf signifikansi $5 \%$ berarti hipotesis Nol disetujui atau diterima dan hipotesis alternatif ditolak, sedangkan pada taraf signifikansi $1 \% r_{x y}$ $<\mathrm{r}$ tabel yang berarti hipotesis Nol disetujui atau diterima dan hipotesis alternatif ditolak. Jadi kesimpulannya adalah bahwa tidak ada pengaruh antara model pembelajaran kooperatif tipe TPS (Think Pair Share) terhadap pemahaman siswa pada mata pelajaran Fiqih kelas VII di MTs Al Irsyadiyah Dermolemahbang Sarirejo Lamongan.

Dari nilai rxy yang diperoleh sebesar 0,208 selanjutnya dikonsultasikan pada tabel interpretasinya antara 0,20 - 0,40 maka model pembelajaran kooperatif tipe TPS terhadap pemahaman siswa terhadap mata pelajaran Fiqih kelas VII di MTs Al Irsyadiyah adalah terdapat korelasi yang lemah atau rendah.

\section{F. Kesimpulan}

Dari hasil analisis data yang telah dikumpulkan, maka dapat diambil kesimpulan sebagai berikut: Pertama, model pembelajaran kooperatif tipe TPS (Think Pair Share) yang dilaksanakan di MTs Al Irsyadiyah adalah tergolong baik. Hal ini terbukti dari data angket yang sudah dianalisa peneliti dengan hasil prosentase $80,2 \%$. 
Kedua, tentang pemahaman siswa pada mata pelajajaran Fiqih juga tergolong baik. Hal ini terbukti dari data angket dengan hasil prosentase $69,9 \%$. Ketiga, dalam penggunaan model pembelajaran kooperatif tipe TPS (Think Pair Share) terhadap pemahaman siswa pada mata pelajaran Fiqih adalah terdapat korelasi namun tidak berpengaruh. Hal ini terbukti berdasarkan analisa data yang dilakukan dengan menggunakan product moment yang menghasilkan nilai $r_{x y}$ sebesar 0,208 . Apabila nilai $\mathrm{r}_{\mathrm{xy}}$ tersebut dikonsultasikan dengan taraf signifikansi $5 \%=$ 0,316 dan $1 \%=0,408$ maka nilai $r_{x y}$ lebih kecil dari nilai $r$ tabel. Dengan demikian Ha ditolak dan Ho diterima atau disetujui. Dan apabila $r_{x y}$ dikonsultasikan dengan tabel interpretasi nilai " $r$ " maka antara variabel $\mathrm{x}$ dan variabel y terdapat korelasi yang lemah atau rendah.

\section{DAFTAR PUSTAKA}

Anas Sudijono, Pengantar Statistik Pendidikan (Jakarta: Raja Grafindo Persada, 2008).

Isjoni, Pembelajaran Kooperatif Meningkatkan Kecerdasan Komunikasi Antar Peserta Didik (Yogyakarta: Pustaka Pelajar, 2009).

Sutrisno Hadi, Metodoligi Reseach, Jilid I (Yogyakarta: Andi Offset, 1980). Suharsimi Arikunto, Prosedur Penelitian: Suatu Pendekatan Praktik (Jakarta: PT. Rineka Cipta, 2006). 